Article

\title{
Study on the Influence of Land Use on Water Environment Quality in Riverside Zone Based on GIS
}

\author{
Yu Zhao ${ }^{1,2, * \mathbb{C}}$, Qingwei Yang ${ }^{1}$ and Peiyin Yuan ${ }^{1,3}$ (1) \\ 1 College of River and Ocean Engineering, Chongqing Jiaotong University, Chongqing 400074, China; \\ liana-zhao@hotmail.com (Q.Y.); yuanpy@cqjtu.edu.cn (P.Y.) \\ 2 College of Architecture and Urban Planning, Chongqing Jiaotong University, Chongqing 400074, China \\ 3 College of Shipping and Naval Architecture, Chongqing Jiaotong University, Chongqing 400074, China \\ * Correspondence: zhaoyucq@cqjtu.edu.cn
}

Received: 13 January 2020; Accepted: 11 February 2020; Published: 13 February 2020

\begin{abstract}
The development of the urban Binjiang belt has influenced the water environment quality. Taking the Chongqing section of the Yangtze River basin and the Binjiang section of the urban center as examples, representative water intake points were selected to extract the urban layout pattern of the Binjiang belt, and the distribution characteristics of its influence on water environment quality were studied using a geographic information system. A structural equation model was used to establish a model of the influence of urban layout on water environment quality, and the water quality test results were added to the model to calculate the contribution rates of different land types to water environment quality. The research results and methods can be used for reference for urban water environment quality and for evaluating the influence of urban design on water environment quality.
\end{abstract}

Keywords: riverside belt urban layout form; land use; structural equation model; water environmental quality

\section{Introduction}

Since the beginning of the industrial revolution in the 18th century, urban waterfront land has largely been transformed into industrial production belts due to convenient water resources and transportation conditions, thereby worsening urban river and lake system water environments [1]. After the end of the industrial era, countries realized the seriousness of urban water pollution [2]. The construction and rapid development of a city considerably impacts the river flowing through the city. As the Yangtze River basin is one of the regions with the most potential for future economic growth in China, the environmental pollution caused by rapid development cannot be ignored. Researchers are paying more attention to policy-oriented management methods and spatial distribution changes of different types of pollution elements, whereas the influences of urban construction land and urban space planning on water environment quality have been ignored [3]. Pollution control systems in the process of urban design have been studied [4]. In 2014, China launched overall planning work for the 24 environments of the city; the core content is the designation of a technical framework of the urban water environmental system, water conservation, water environmental function areas, aquatic wildlife nature reserve, and aquatic resources reserves, and scenic spots, to establish a red line division of the water environment system. The coordinated control of water unit area, groundwater pollution prevention, and control zoning were combined to build a spatial planning system suitable for urban development [5]. 
Urbanization has a certain impact on river water quality. The water quality of the river section flowing through a city is seriously worse than that of the upper reaches, and the groundwater is also polluted to a certain extent [6]. Scholars developed an integrated city drainage model that considers typical urban forms and their associated drainage infrastructures, specifically domestic wastewater and rainwater systems, to analyze the relationship between them. The model was used to evaluate the randomly configured drainage system in a virtual city [7].

The low impact development (LID) theory of cities proposes that the development area should be as close as possible to the natural hydrologic cycle before development, so that cities can exist in harmony with nature [8]. Waterfront space development should be aligned with the river water system model with as low as possible environmental impact to prevent shrinking the river water system, fragmenting the structure, and degrading the ecological function through efficient and intensive use of land, municipal facilities, roads, ecological waterfront green spaces, with waterfront land development and river drainage in harmonious coexistence [9]. Another theory related to urban planning and water environment is sponge city theory, which enables cities to have good resilience to adapt to environmental changes and cope with natural disasters. Rachel May studied spatial urban waterfront construction, and reported that the urban design of waterfront should combine the inherent natural characteristics and historical traditions of the city, and create identifiable elements of urban design of waterfront from the aspects of skyline design, landscape landmarks, and architectural form [10]. Dublin real estate uses the WSUD (water sensitive urban design) system to combine buildings, roads, street views, public open spaces, and a storm water management system to reduce the impact of new projects on the surrounding environment and reduce the amount of suspended solids, nitrogen, phosphorus, and heavy metal pollutants entering the local water system ( $90 \%$ suspended solids, $80 \%$ phosphorus, and 60\% nitrogen in runoff) [11]. Ecological infrastructure (EI) and scientific theories on human settlement environment have been introduced. These theories focus on the relationship between city and environment, urban construction, and water environment.

Research is lacking on the impact of land use/urban planning in urban centers on water quality. A statistical relationship was discovered between land use and land cover and surface water and groundwater [12,13]. Long-term observation data were used to predict the mutual influence between water quality and human activities. Dynamic land use/land cover maps were obtained using remote sensing data, which were analyzed with ArcGIS software, the area with suitable water quality was determined, and suggestions were provided for urban planning and management decision-making $[14,15]$.

Many scholars have studied the spatio-temporal influence of urban land use on urban water quality trends [16]. From the published studies, we found that few scholars discussed the impact of urban space planning and design on the quality of the regional water environment.

This study was conducted in Chongqing in Western China, which lies along the edge of the Yangtze River. The study area is located in the Nanan district of the metropolitan area in Chongqing, which provides business, tourism, residential, industrial, and other urban functions. Over the past decade, rapid growth has resulted in the urbanization of large areas of rural land along the urban fringe as well as major residential, commercial, and industrial redevelopment in existing urban areas [17]. The research area is at the center of the city. The Yangtze River section occupies nearly two-thirds of the whole area, and the river coastline is $40 \mathrm{~km}$. The water system mainly consists of the Yangtze and Jialing Rivers and their tributaries, such as the Kuxi, Daxi, Yipin, and Huaxi River and 20 other rivers. The main stream of the Yangtze River enters from Ertang village in the southwest and proceeds to Mingyue to in the east, about $51 \mathrm{~km}$ in length. The main drainage system is shown in Figure 1. 


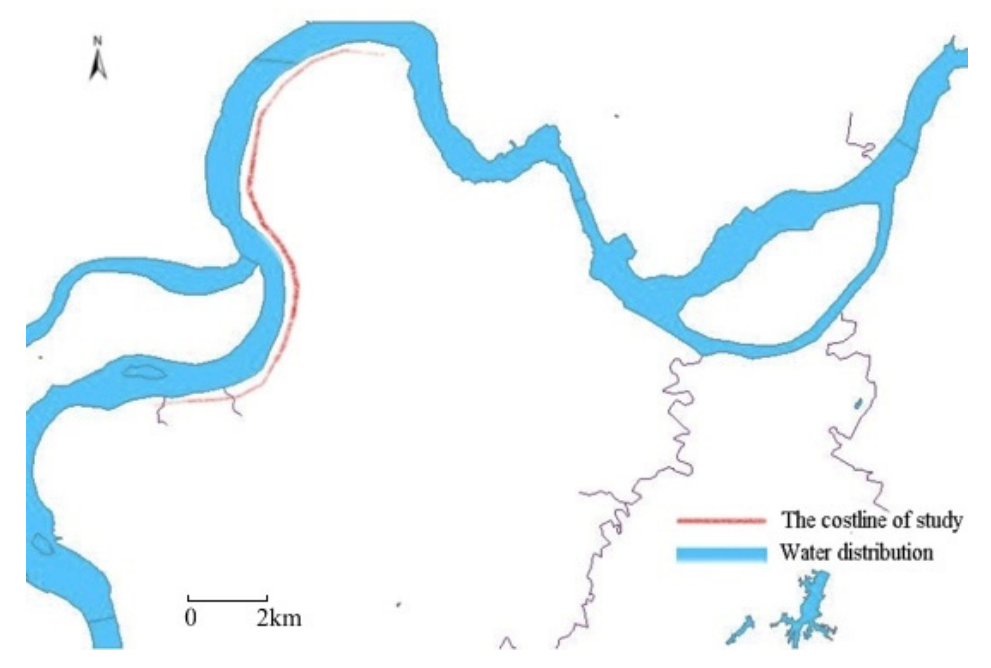

Figure 1. The water system distribution map of the main urban area of Chongqing.

\section{Materials and Methods}

\subsection{Sampling Sites and Methods}

The total length of the river section considered in this study was $15 \mathrm{~km}$. Satellite images were used as the basic information source, and remote sensing images were interpreted and vectored to obtain vector data of the south bank area. Based on the current land use, urban functional zoning, and the field investigation results, we drew a schematic diagram of land use and functional zoning is, as shown in Figure 2. Combined with the construction land planning of the main urban area in 2014 , the main types of land used in the riverside section of south bank were divided into residential land, commercial service facility land, green land and square land, and public management and public service facility land. Large residential areas included Coral Water Bank, Haitang Xiaoyue, Wuyi Riverside, Sunshine 100 International New City, etc. Large commercial areas included Dongyuan 1891, Changjiahui shopping park, etc. (Figure 3). The study area included seven sewage outlets and two drinking water protection areas, which are the first and secondary protected area, respectively, located on the left and right side of Dongshuimen Bridge, respectively.

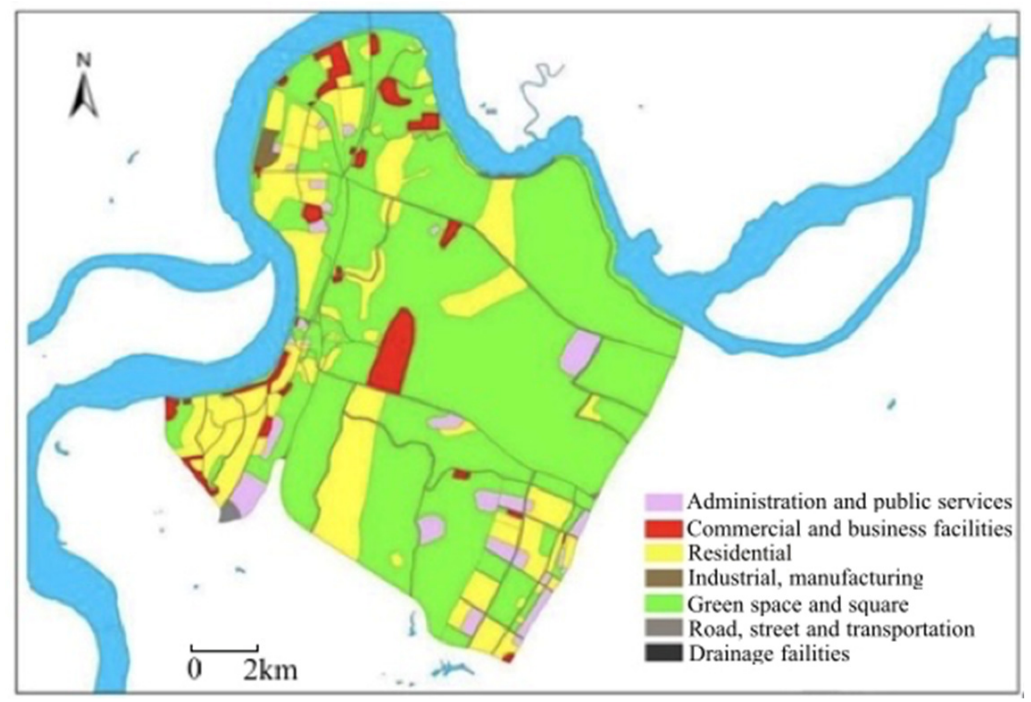

Figure 2. Land use and functional classification. 


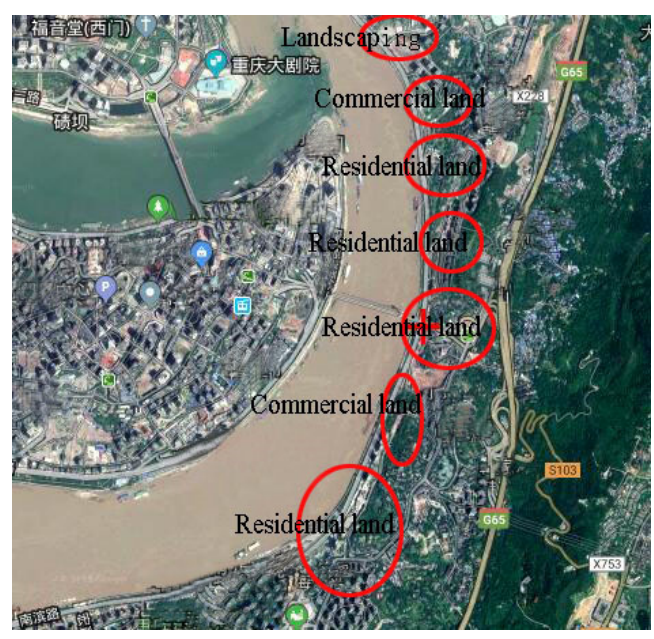

Figure 3. Functional layout of land use along the river.

In this study, we focused on total phosphorus (TP), total nitrogen (TN), and chemical oxygen demand (COD) due to their recognized impacts on aquatic ecosystems and typical association with urban areas across the region (regulations on the division of drinking water source protection zones in Chongqing, 2002).

First, the waters in the study were monitored for one year. After a long-term sampling test, we found that within the studied shoreline length, the data at each sampling point did not change significantly in some time periods. Secondly, due to the three periods of high water, low water, and flat water, the main body of economic development along the Yangtze River differs, resulting in different sources of pollution during different water periods. Therefore, we discussed problems according to different water periods. The study area has high construction density, which is a typical urban center/riverside area, different from the whole city (the area studied is relatively large). Finally, considering the uncertainties of long-term observation data sampling, three samples were obtained at the same sampling point each time. If the error difference between two groups of samples was $5 \%$, resampling was conducted. If the error difference was less than $5 \%$, the average value of the three groups was taken as the final measurement result.

For these four reasons above, water samples were collected from 10 different areas along Nanbin Road along the Yangtze River in May and October 2019. The two sampling times were selected because May and October are before and after the Yangtze River flood season. Analyses were undertaken by accredited laboratories using standard methods and procedures: HJ 495-2009, TP and heavy metals-GB 11893-89, and HJ 636-2012 in China. According to Water Quality-Guidance on Sampling Techniques of Rivers, HJ/T 52-1999, the sewage discharged into most rivers can be fully vertically mixed within $1 \mathrm{~km}$. In this case, a sampling point can be arranged at any depth in the vertical direction.

Ten water extraction points were selected in this study, as shown in Figure 4. Point A is a gathering place for hotels and other commercial service facilities, located under the Yangtze River bridge. Point B is a sewage outlet in Huangge Wandu, surrounded by high-rise residential areas and several super high-rise hotels. Point $C$ is located in Yanyu Park; nearby are high-rise residential groups and supporting businesses along the street; a sewage outlet exists near point $\mathrm{D}$, which is a secondary protection area for drinking water. Point $\mathrm{E}$ is at the lower left of East Watergate. A sewage outlet is nearby and a university is $1 \mathrm{~km}$ away (Chongqing Institute of Socialism). Point $\mathrm{F}$ is located on the right side of Dongshuimen Bridge, near a sewage outlet. The water pollution is serious, and the water surface is yellowish. Point $G$ is $100 \mathrm{~m}$ from point $\mathrm{F}$. There is a sewage outlet nearby. Point $\mathrm{H}$ is located in Sunshine 100 International New City, surrounded by small super high-rise residential areas. Point I is located in Changjiang Art Plaza, with the Chongqing Cigarette Factory and Experimental Middle School within $1 \mathrm{~km}$; Point $\mathrm{J}$ is located in Changjiahui shopping park (a large commercial center), surrounded by high-rise residential areas. 


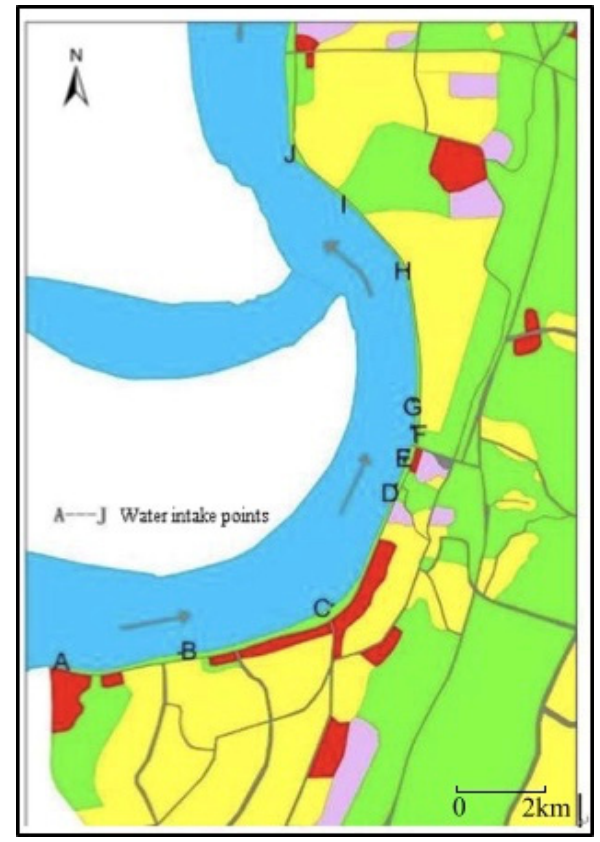

Figure 4. Water sampling sites at the south bank of Yangtze River in Chongqing.

To facilitate the research and protection of urban environment and water quality, Chongqing municipality has unified the monitoring time of surface water quality in the Yangtze, Jialing, and Wujiang Rivers since 2011. The samples were taken $48 \mathrm{~h}$ after rain to avoid the dilution of water pollutants by rain, which would interfere with the research results. The sampling occurred from 07:00 to 10:00 a.m. to avoid volatilization caused by sunlight on the collected water samples. According to the sample volume regulation (Table 1) of the standard inspection index for drinking water, the water receiver was a $380 \mathrm{~mL}$ plastic bottle. Sampling occurred in hydrometric sections in the waterbed cross-section. Before sampling water, the water sampler was flushed three times with the substitute sample to ensure the water sample filled the container. After collecting the water sample, we measured the $\mathrm{pH}$ of the water sample immediately, then added concentrated sulfuric acid and adjusted the water sample to $\mathrm{pH} \leq 2$, then refrigerated it at $4{ }^{\circ} \mathrm{C}$ to inhibit the metabolic process of microorganisms. The samples were sent to a laboratory for testing as soon as possible to prevent the deterioration of the sample. To prevent sudden changes in water quality at the intake point from affecting the measurement results, three samples were collected around each intake point for analysis. Research shows that such sampling method can reflect the average variation of concentration [18].

Table 1. Test method of each index.

\begin{tabular}{cccc}
\hline Indicators & Methods & Instrument & Standard \\
\hline $\mathrm{pH}$ & Glass electrode method & pH meter & GB 6920-86 \\
\hline COD & $\begin{array}{c}\text { Rapid digestion } \\
\text { spectrophotometry }\end{array}$ & SpeedDigester, DRB200 & $\begin{array}{c}\text { Methods for monitoring } \\
\text { and analyzing water and } \\
\text { wastewater }\end{array}$ \\
\hline TP & $\begin{array}{c}\text { Basic potassium } \\
\text { persulfate digestion } \\
\text { ultraviolet } \\
\text { spectrophotometry }\end{array}$ & $\begin{array}{c}\text { UV/VIS } \\
\text { spectrophotometer, } \\
\text { UV-2450 SHIMADZU }\end{array}$ & $\begin{array}{c}\text { Methods for monitoring } \\
\text { and analyzing water and } \\
\text { wastewater }\end{array}$ \\
TN & $\begin{array}{c}\text { Ammonium molybdate } \\
\text { spectrophotometric } \\
\text { method }\end{array}$ & $\begin{array}{c}\text { UV/VIS } \\
\text { spectrophotometer, } \\
\text { UV-2450 SHIMADZU }\end{array}$ & $\begin{array}{c}\text { Methods for monitoring } \\
\text { and analyzing water and } \\
\text { wastewater }\end{array}$ \\
\hline
\end{tabular}


In addition to the water quality data set, we collected 15 other types of data (summarized in Table 1) on planning, infrastructure, land use, topography, and climate indicators to serve as our independent variables for the analysis.

\subsection{Analysis of Laboratory Results}

The $\mathrm{pH}$ value of all sampling points was 6-9, and all samples met the environmental quality standards for surface water. At sampling point $B, C O D>45$ failed to meet the water quality safety index. The measuring point was surrounded by high-grade residential areas. At D point, COD $>45$. Nearby is a university, with a total construction area of $900,000 \mathrm{~m}^{2}$, and a five-star city tourist attraction project. As shown in Table 2, the COD value of point $\mathrm{H}$ was higher than 45, with small high-rise residential groups, a middle school (Chongqing Binjiang Experimental Middle School, Binjiang, China), and a hospital nearby. The COD at point J was 390, which is much higher than the standard limit for COD concentration. To verify the results, another sampling was conducted and the detection results were similar to the first. The urban functions near point $J$ include high-rise residential areas and commercial centers, with a concentrated population. The other indexes of each measuring point met the environmental quality standards for surface water.

Table 2. Test results of various indicators.

\begin{tabular}{ccccc}
\hline Sampling Point & $\mathbf{p H}$ & COD $(\mathbf{m g} / \mathrm{L})$ & TN $(\mathbf{m g} / \mathbf{L})$ & TP $(\mathbf{m g} / \mathbf{L})$ \\
\hline A & 7.5 & 12 & 0.217371 & 0.069283 \\
B & 7.56 & 49 & 0.235464 & 0.031492 \\
C & 7.56 & 5 & 0.243218 & 0.144865 \\
D & 7.57 & 49 & 0.207032 & 0.056686 \\
E & 7.59 & 24 & 0.225125 & 0.107074 \\
F & 7.54 & 19 & 0.22771 & 0.056686 \\
G & 7.49 & 30 & 0.444822 & 0.119671 \\
H & 7.6 & 60 & 0.26648 & 0.119671 \\
I & 7.58 & 25 & 0.214786 & 0.006298 \\
J & 7.56 & 390 & 0.248387 & 0.056686 \\
\hline
\end{tabular}

As shown in Figure 5, the residential group near point B is close to the river, with a plot ratio of less than 2.0, and has sufficient green areas. High-rise buildings and multi-story buildings are adjacent to the river. This kind of layout is more common in riverside areas. The aerial picture shows that there was a large amount of unused land near the river at point $\mathrm{D}$, with few traces of human activity. In addition, there is a basketball court. The shoreline here has not been over-developed. The government has strictly stipulated the floor area ratio and building height of this area.

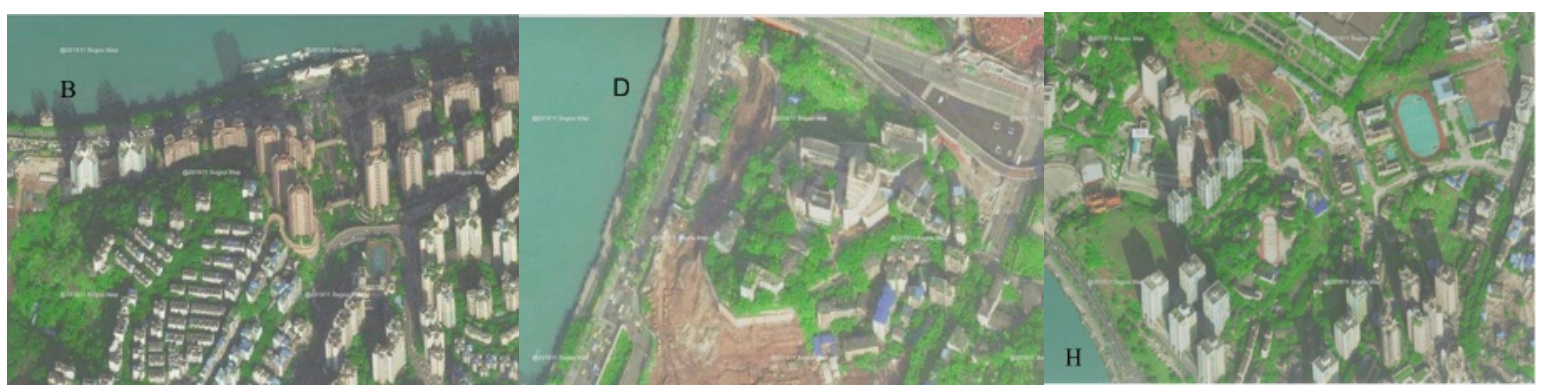

Figure 5. Typical urban environment and architectural layout near the four measuring points (B, D, H). 


\section{Model of Relationship between Water Pollution and Land Use}

\subsection{Modeling}

To establish the relationship between refined land use and the water quality of the riverside segment in the study area, we selected evaluation factors according to the standards for surface water environmental quality, and the structural equation model (SEM) of the impact of land use types on water environmental quality was established. The results were sampled by bootstrapping, and 300 model samples were generated to meet the demand of the SEM for a larger sample size. Maximum likelihood estimation was used to quantify the SEM and to determine the model structure and the standardized coefficient [19]. Then, the contribution rate of different land use types to water environment quality was calculated to determine the influence of spatial planning and design of the riverside region in Nanan district on water environment quality. Structural modeling visually describes the relationship between latent variables through a path diagram, whereas the measurement model describes the relationship between latent variables and measured variables through factor analysis. Latent variables represent phenomena that cannot be directly measured, whereas the measurement variables represent phenomena that can be directly measure [20]. This model has furthered research on lake water quality and the human and land relationship due to its multivariate analysis skills and strong ability to deal with intricate relationships, which provided technical support for the study of the complex relationship between land use and water environment quality.

The measurement model is

$$
\begin{aligned}
& X=\Lambda_{X} \xi+\delta \\
& Y=\Lambda_{Y} \eta+\varepsilon
\end{aligned}
$$

where $\xi$ is the exogenous latent variables, $X$ is the factor of the exogenous variable measurement of $\xi$, $\Lambda_{\mathrm{X}}$ is the exogenous variable measurement in the relationship between the coefficient of exogenous latent variables, $\delta$ is the residual of exogenous equation, $\eta$ is the endogenous latent variable, $Y$ is the endogenous variable of $\eta, \Lambda_{Y}$ is the endogenous latent variables in the relationship between the endogenous variable measurement coefficient, and $\varepsilon$ is the residual of the endogenous equation [21].

The structural model is

$$
\eta=B \eta+\Gamma \xi+\zeta
$$

where $B$ is the relationship coefficient between endogenous latent variables, $\Gamma$ is the exogenous latent variables in the relationship between the endogenous latent variable impact coefficient, and $\zeta$ is the residual of the equation.

The process of water cycle includes evaporation, transportation, precipitation, infiltration, and runoff. Evaporation, precipitation, and runoff are the three most important links in the water cycle, and are the key to the balance of the earth's water and the total amount of water resources in various regions. Land use is the connection point of atmosphere, hydrosphere, lithosphere, and biosphere, and it is an important factor affecting water evaporation and runoff [22]. Therefore, the evaluation and analysis of water environment quality should be conducted from the two aspects of water environment and external influencing factors. The mutual influence relationship between land use and water environment (including internal factors and external influencing factors) should be established to study the influence of land use on water environment quality [23]. In this study, the water quality and upstream water quality sources were simplified and assumed to simplify the calculation process. The water environment was characterized using the upstream water quality and purification capacity. The external factors are expressed by pollution load, including point source load. Figure 6 depicts a path diagram based on the above analysis. 


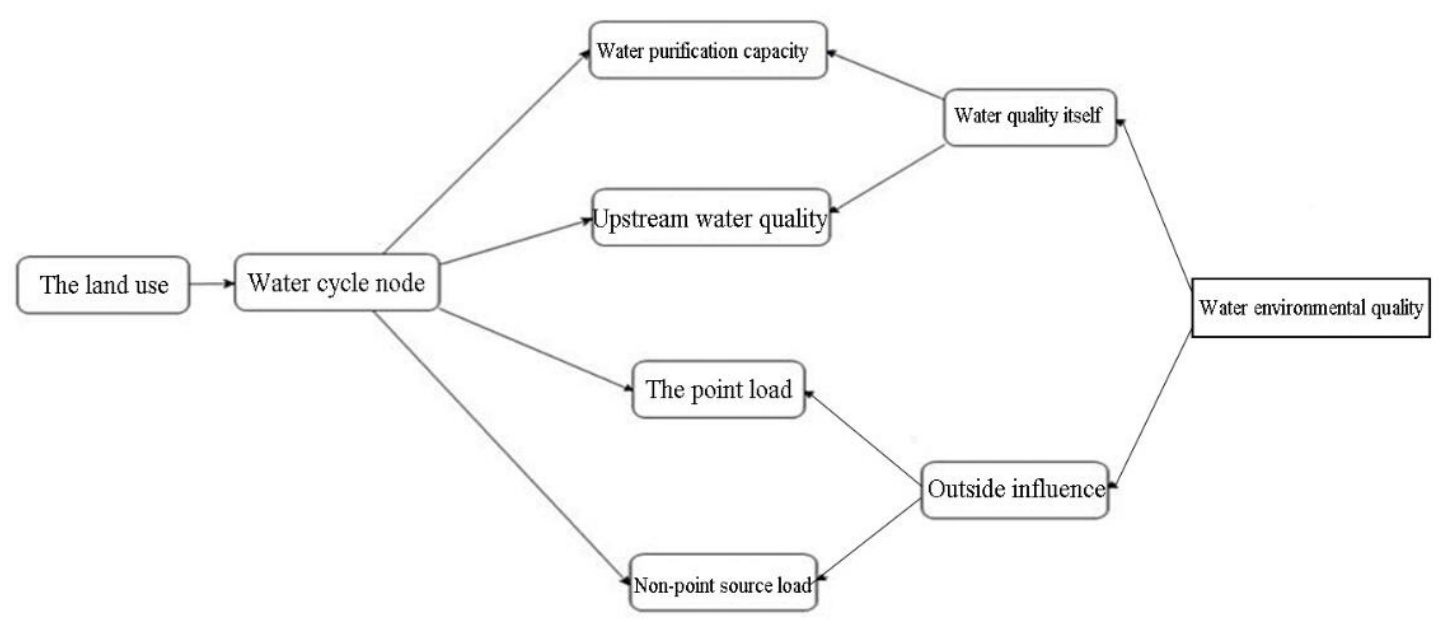

Figure 6. Influence path of land use and urban spatial planning on water quality.

\subsection{Selection of Latent Variables and Measurement Variables}

Seven variables, including water environment quality, water environment, external influence of water environment, water quality purification capacity, upstream water quality, and point source load, were selected as potential variables for the SEM, and corresponding measurement variables were selected for each potential variable. As shown in Table 3, COD, TP, and TN were selected to represent the measurement variables of five potential variables including water environment quality, water environment status, external influence of water environment, water quality of upstream incoming water, and point source load. River meandering and proportion of green land area were used to represent the purification ability of water quality because large wetlands can intercept more pollutants and improve their residence time in wetlands, which is conducive to water quality purification [24]. Rivers with high meandering degree have more abundant plants and microorganism resources and stronger self-purification ability [25]. The selection of load measurement variables for non-point source pollution focused on the influence of different land use types in the process of non-point source pollution, such as construction land to reduce water seepage and vegetation interception. Urban green space increases rainwater infiltration, reducing the impact of land development on the surrounding water environment. Therefore, the construction land area and green land area were selected as variables measuring non-point source pollution load.

Based on the calculation results of the above SEM, the contribution rate of each land use index to water environment quality was calculated according to the action coefficient of each variable. Assuming that $i$ is the latent variable that directly affects the water environment quality and $j$ is the passing latent variable, the contribution of the latent variable to the water environment quality in the SEM was calculated as

$$
P_{i j}=\frac{|X i \cdot Y i j|}{\sum_{i=1, j=1}|X i \cdot Y i j|} \times 100 \%
$$

where $P_{i j}$ is the contribution rate of latent variables to water environment quality $X i$ is the coefficient directly on water environment quality, and $Y i j$ is the coefficient directly influencing latent variable $i$ through latent variable $j$. Xi.Y $i j$ is the indirect influence coefficient of latent variable $j$ on water environment quality through latent variable $i$. The contribution of measured variables to water environment quality in the SEM was calculated as

$$
P_{i j}=P_{i j} \frac{|Z j|}{\sum_{j=1}|Z j|} \times 100 \%
$$

where $P_{i j}{ }^{*}$ is the contribution rate of measured variables to water environment quality in the model and $Z_{j}$ is the factor loading of different measurement variables on the corresponding latent variables. 
Table 3. Structural equation model (SEM) measurement variables and potential variables.

\begin{tabular}{ccc}
\hline Latent Dependent Variable & Variable & Unit \\
\hline \multirow{2}{*}{ Water environmental quality } & COD & $\mathrm{mg} / \mathrm{L}$ \\
& $\mathrm{TP}$ & $\mathrm{mg} / \mathrm{L}$ \\
\hline \multirow{2}{*}{ Water purification capacity } & TN & $\mathrm{mg} / \mathrm{L}$ \\
\hline \multirow{2}{*}{ Water environment } & Green area ratio & $\%$ \\
& River meandering & - \\
\hline \multirow{2}{*}{ Water environment external } & COD environmental capacity & $\mathrm{t}$ \\
influence & TN environmental capacity & $\mathrm{t}$ \\
& COD emissions & $\mathrm{t}$ \\
\hline \multirow{2}{*}{ Upstream incoming water quality } & TP emissions & $\mathrm{t}$ \\
& TN emissions & $\mathrm{t}$ \\
\hline & COD concentration & $\mathrm{mg} / \mathrm{L}$ \\
& TP concentration & $\mathrm{mg} / \mathrm{L}$ \\
& TN concentration & $\mathrm{mg} / \mathrm{L}$ \\
\hline Point source load & COD point source emissions & $\mathrm{t}$ \\
\hline & TP point source emissions & $\mathrm{t}$ \\
\hline & TN point source emissions & $\mathrm{t}$ \\
\hline
\end{tabular}

\subsection{Variable Calculation}

\subsubsection{Area Percentage of Each Land Use Type}

The area of each land use type was calculated to obtain the area percentage of different land use types, as shown in Table 4.

Table 4. Proportion of different land use types.

\begin{tabular}{ccc}
\hline Land Use Type & Area $\mathbf{( m}^{\mathbf{2}}$ ) & Proportion $\mathbf{( \% )}$ \\
\hline Residential land & $24,659,579$ & 0.221 \\
Commercial and service facility land & $4,743,765$ & 0.042 \\
Green and square land & $76,816,428$ & 0.687 \\
Land for public administration and public service facilities & $5,371,766$ & 0.048 \\
Industry & 156,060 & 0.001 \\
\hline
\end{tabular}

\subsubsection{Calculation of the River Mean Values}

River meandering was determined by the ratio of the river center line to the river basin center line [26]. The calculation formula was

$$
\begin{gathered}
S=L_{r} / L_{v} \\
S=4.6 / 10=0.46
\end{gathered}
$$

3.3.3. External Influence of Water Environment

The calculation formula of domestic sewage discharge is

$$
\mathrm{Q}_{\mathrm{s}}=\mathrm{KQ}_{1} \mathrm{~V}_{1} / 1000
$$

where $Q_{s}$ represents the sewage discharge from the living area ( $t /$ day), $Q_{1}$ is the daily domestic sewage quantity quota per person, $\mathrm{V}_{1}$ is the number of people living in the area, $\mathrm{K}$ is the sewage discharge 
coefficient, which is generally $0.6-0.9$, and 0.9 was selected as the coefficient according to the location of the research area. Table 5 lists the pollutant concentration parameters.

Table 5. Pollutant concentration parameters.

\begin{tabular}{|c|c|c|c|}
\hline Land Use Type & $\operatorname{COD}\left(\mathrm{kg} / \mathrm{cm} \cdot \mathrm{km}^{2}\right)$ & $\mathrm{TN}\left(\mathrm{kg} / \mathrm{cm} \cdot \mathrm{km}^{2}\right)$ & $\mathrm{TP}\left(\mathrm{kg} / \mathrm{cm} \cdot \mathrm{km}^{2}\right)$ \\
\hline Residential area & 51 & 5.8 & 1.5 \\
\hline Business district & 207 & 13.1 & 3.3 \\
\hline Industrial area & 78 & 12.2 & 3.1 \\
\hline Other land & 9 & 2.7 & 0.4 \\
\hline
\end{tabular}

According to the pollutant concentration parameters of each land use type and the calculation formula for domestic sewage discharge, the pollutant discharge of each land use type was obtained. The discharge of pollutants from different types of land use (urban drainage and sewage treatment regulations) in the research area was calculated and weighted by a geographic information system (GIS) with water quality. Bootstrapping was used to combine the two kinds of data into a new dataset. According to the pollutant emission concentration distribution in the research area, the land use was divided into four categories: areas of general, severe, minor, and basically no impact.

Figure 7 shows that the output of COD, TP, and TN in the upstream was small, with higher distribution in the downstream. The COD, TN, and TP emission concentrations were the highest in the residential land. Residential areas (including rural settlements) were the main factors affecting water quality in this region. The discharge of domestic sewage is the main factor causing the deterioration of water environment quality, followed by commercial land and public service land. The relationship between pollutants in rivers and land use is well understood. Residential areas and some rural settlements show a strong correlation with the concentration of pollutants in rivers. The relationship between pollutant concentration and different types of land gradually decreases as the distance from the river increases, and only some residential areas still impact pollutant concentration in the river.

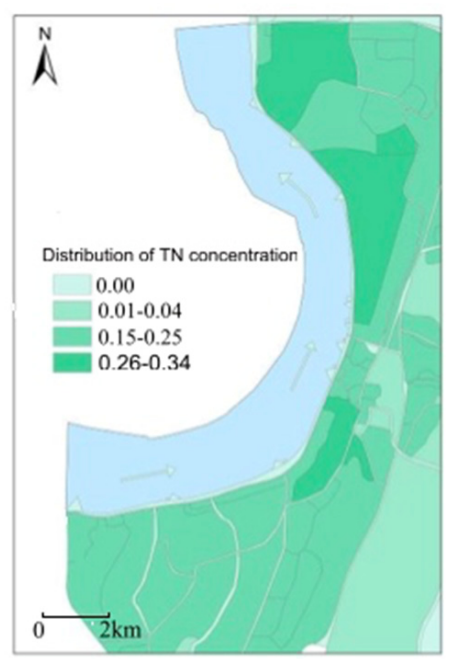

(a) TN

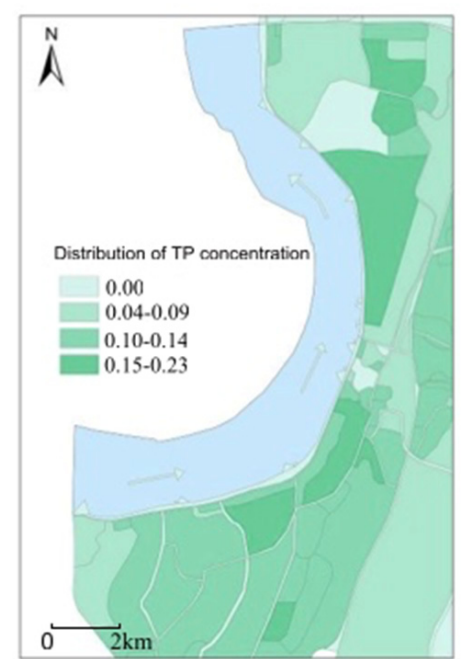

(b) TP

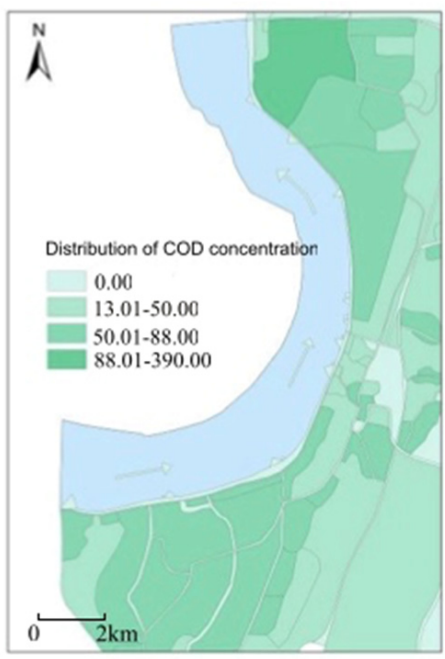

(c) COD

Figure 7. Relationship of pollutant emission distribution, pollutant emission level, and functional division and (a) TN, (b) TP, and (c) COD concentration in each division.

\section{Analysis of Water Environment Quality by Urban Function Division}

AMOS was used for path analysis. Data obtained from the data search and field research were first imported into SPSS and saved in "sav" format. The standardization function coefficient in the SEM was used to reflect the relationship between latent variables and measured variables, and latent variables and the correlation of the water environment quality. To verify the fitting degree and the 
effective degree of the SEM, we selected several commonly used indexes (absolute index, relative index, and contracted index). As shown in Table 6, all indexes were within the range of the fitting standard, so the fitting degree of this model is considered good and met the study requirements.

Table 6. Results of SEM fitting calculation.

\begin{tabular}{cccccccc}
\hline Index & \multicolumn{3}{c}{ Absolute Index } & \multicolumn{2}{c}{ Relative Index } & \multicolumn{2}{c}{ Parsimony Fit Index } \\
\hline $\begin{array}{c}\text { Configuration } \\
\text { identification index }\end{array}$ & $\chi^{2} / \mathrm{df}$ & RMSEA & GFI & NFI & CFI & PNFI & PCFI \\
\hline Fitted value & 2.976 & 0.077 & 0.936 & 0.904 & 0.931 & 0.505 & 0.514 \\
\hline Standard values & $<3$ & $<0.08$ & $>0.9$ & $>0.9$ & $>0.9$ & $>0.5$ & $>0.5$ \\
\hline
\end{tabular}

The direct effect coefficient of external water environment on water environment quality was 0.78 , indicating that an increase in COD, total nitrogen, and total phosphorus emissions will lead to the deterioration of water environment quality and more serious pollution. The effect coefficient of the water environment on water environment quality was -0.56 , indicating that an increase in pollutant environmental capacity improves water environment quality and positively affects water environment quality. By comparing the effect coefficient, we found that the external influences of the water environment were greater than the water environment itself, indicating that the effects of pollution caused by human production and living activities on water quality are stronger than the sustainability of the water body, so water quality is affected and polluted. Figure 8 depicts the standard action coefficient. The upstream water quality and purification capacity indirectly affected the water environment quality by affecting the water environment. An increase in pollutant concentration in the upstream water had a negative impact on the water environment and indirectly led to the deterioration of water environment quality. The purification capacity of water quality positively impacted the water environment. The stronger the purification capacity of water, the better the water environment; the higher the environmental capacity of pollutants, the better the water environment quality. Point source and non-point source load, by externally influencing the water environment, indirectly impact water environment quality. Increases in point source and non-point source loads negatively impacted water environment quality. Water environment quality, including the role of the point source pollution coefficient, has a much larger influence than the effect coefficient of non-point source pollution, illustrating that the point load is an important factor affecting the water environment quality. Therefore, controlling point source pollution and pollutant discharge is important for improving water environment quality.

As shown in Table 7, the contribution of each measurement variable to water environment quality was calculated using the contribution rate calculation formula. The contribution rates of upstream water quality, water quality purification capacity, point source load, and non-point source load to water environment quality were $20.85 \%, 18.37 \%, 40.54 \%$, and $20.24 \%$, respectively. This indicates that point source load was the most important factor affecting the water environment quality and the discharge and concentration of various pollutants are still the main reasons for the deterioration of water quality. For the point source load, COD point source emissions accounted for the largest proportion, $7.34 \%$, indicating that the main pollutant in the Yangtze river is COD, which is consistent with the water quality indicators measured by our field investigation and the laboratory. Total nitrogen and total phosphorus emissions accounted for a relatively small proportion of COD, at $4.31 \%$ and $3.13 \%$, respectively. The upstream factors influencing water quality were the next highest, suggesting that need to partition regional water environment management and governance of sewage, especially in the jurisdiction of the upper reaches. Upstream COD accounted for the largest proportion of all the data, followed by total nitrogen and total phosphorus. The contribution rate of non-point source load was $20.24 \%$, that of green space was $9.48 \%$, and construction land contributed $8.31 \%$, indicating that urban greening planning had a positive impact on the city's environmental quality. Increasing the proportion 
of green land in construction land can effectively improve the quality of the water environment. The contribution rate of water quality purification capacity was $18.37 \%$, so an appropriate increase in wetland area would improve water quality.

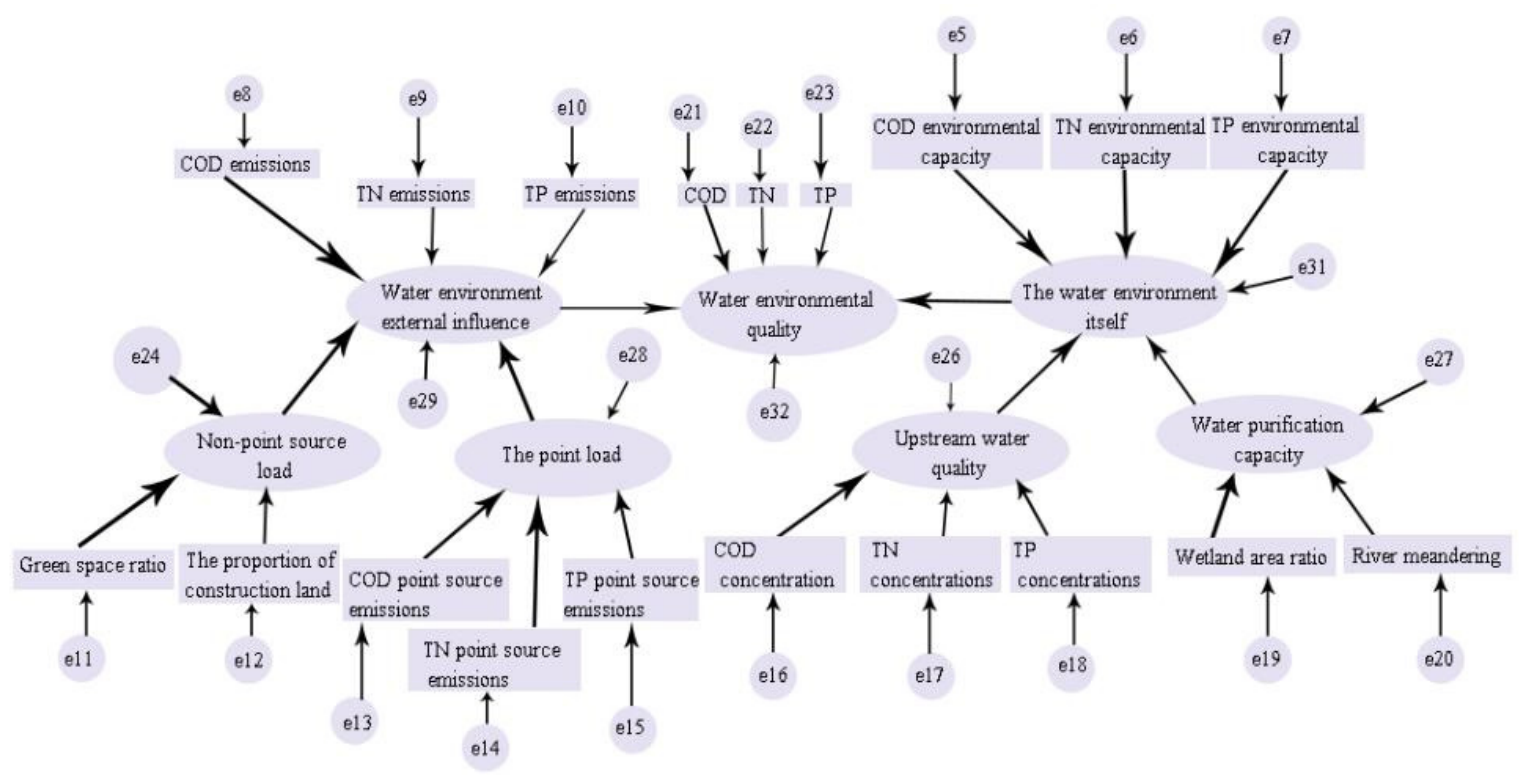

Figure 8. Standard action coefficient.

Table 7. Calculation of contribution rates of different measurement variables to water environment quality.

\begin{tabular}{|c|c|c|c|c|}
\hline Objective & Latent Variable & Contribution (\%) & Measured Variable & Contribution (\%) \\
\hline \multirow{10}{*}{$\begin{array}{c}\text { Water } \\
\text { Environmental } \\
\text { quality }\end{array}$} & \multirow{3}{*}{$\begin{array}{l}\text { Upstream water } \\
\text { quality }\end{array}$} & \multirow{3}{*}{20.85} & COD concentration & 9.21 \\
\hline & & & TN concentration & 4.41 \\
\hline & & & TP concentration & 3.19 \\
\hline & \multirow{2}{*}{$\begin{array}{l}\text { Water purification } \\
\text { capacity }\end{array}$} & \multirow{2}{*}{18.37} & Wetland area ratio & 2.94 \\
\hline & & & River meandering & 1.07 \\
\hline & \multirow{3}{*}{ The point load } & \multirow{3}{*}{40.54} & COD point source emissions & 7.34 \\
\hline & & & TN point source emissions & 4.31 \\
\hline & & & TP point source emissions & 3.13 \\
\hline & \multirow{2}{*}{$\begin{array}{c}\text { Non-point source } \\
\text { load }\end{array}$} & \multirow{2}{*}{20.24} & Proportion of construction land & 8.31 \\
\hline & & & Green space ratio & 9.48 \\
\hline
\end{tabular}

\section{Conclusions}

Residential space and human daily activities were the main factors influencing the water quality environment in the study area. In the Binjiang section, the main indicators of water pollutant concentration exceeding the standard were COD, total phosphorus, and total nitrogen, which were mainly elevated in the lower reaches of the Yangtze River. The water pollution was different in different regions. The water environment quality was better around the drinking water protected area, but worse near drainage outlets. Factors affecting the water environmental quality in the study area were mainly point source pollution and anthropogenic pollutants released into the water, providing the compounds affecting COD. TP, TN, and COD emissions are not up to standard, exceeding the environmental capacity. The Binjiang point source pollution must be controlled and the wastewater discharge inspection standard must be strengthened to strictly control the release rate of pollutants. Water environmental quality is closely related to land use and functional zoning of land use. Residential land has the most serious impact on water environmental quality. There are many organic pollutants, such as COD in domestic sewage, which damage water bodies. The influence of commercial land 
on water environment quality is relatively obvious. The water quality index for large commercial areas was lower and the pollution was relatively serious. The influence of public service land on water environment quality was not obvious. Green land was found to significantly affect the improvement of water environment quality; the concentration of water pollutants in areas with a large proportion of green land was significantly lower compared with other areas.

Using GISs is important when visualizing the impact of urban functional zoning on the water environment. However, we only selected obvious residential areas and representative sites, so the zoning could be more detailed. In addition, many indicators were selected from subjective factors, so the objectivity and applicability of the model need to be improved. However, these findings provide reference for the visual analysis of the impact of land use on river pollutant concentration and the relationship between urban functional zoning and water environment quality. The research results can provide a basis for the more scientific planning of urban centers, and determining the proportion of green spaces, parks, and natural ecological areas within an urban landscape.

Author Contributions: Conceptualization, Y.Z.; Data curation, P.Y. and Y.Z.; Formal analysis, Q.Y. and P.Y.; Methodology, Q.Y.; Investigation, P.Y.; Writing-Original draft, P.Y. All authors have read and agreed to the published version of the manuscript.

Funding: This study was financially supported by the Social Science and Technology Innovation Program for People's Livelihood in Chongqing (cstc2017jcyjBX0070, cstc2019jscx-msxmX0302, cstc2018jscx-msybX0233, and cstc2019jscx-lyjsAX0008), and the Science and Technology Program of Chongqing Education Commission (KJQN201900735).

Conflicts of Interest: The authors declare no conflict of interest.

\section{References}

1. Kumar, V.; Parihar, R.D.; Sharma, A.; Bakshi, P.; Sidhu, G.P.; Bali, A.S.; Karaouzas, I.; Bhardwaj, R.; Thukral, A.K.; Gyasi-Agyei, Y.; et al. Global evaluation of heavy metal content in surface water bodies: A meta-analysis using heavy metal pollution indices and multivariate statistical analyses. Chemosphere 2019, 236, 124-364. [CrossRef]

2. Yousaf, B.; Liu, G.; Wang, R.; Imtiaz, M.; Zia-ur-Rehman, M.; Munir, M.A.M.; Niu, Z. Bioavailability evaluation, uptake of heavy metals and potential health risks via dietary exposure in urban-industrial areas. Environ. Sci. Pollut. Res. 2016, 23, 22443-22453. [CrossRef] [PubMed]

3. Zhang, L.L.; Liu, J.L.; He, J.Z.; Li, H. Ecological risk assessment of phthalate pollution level in typical urban water environment in China. J. Ecotoxicol. 2016, 11, 421-435.

4. Wong, T.H.; Eadie, M.L. Water Sensitive Urban Design-A Paradigm Shift in Urban Design. In 10th World Water Congress: Water, the World's Most Important Resource; International Water Resources Association: Paris, France, 2000; p. 1281.

5. Gang, Y.; Gangcai, C.; Yongguan, C. The Econometric Assessment of Losses caused by Water Pollution in Chongqing, Southwest China. Chin. J. Geochem. 2004, 23, 94-100. [CrossRef]

6. Goel, P.; Saxena, A.; Singh, D.S.; Verma, D. Impact of rapid urbanization on water quality index in groundwater fed GomatiRiver, Lucknow, India. Curr. Sci. 2018, 114, 650-654. [CrossRef]

7. Jia, N.; Sitzenfrei, R.; Rauch, W.; Liang, S.; Liu, Y. Effects of Urban Forms on Separate Drainage Systems: A Virtual City Perspective. Water 2019, 11, 758. [CrossRef]

8. De Jong, M.; Joss, S.; Schraven, D.; Zhan, C.; Weijnen, M. Sustainable-smart-resilient-low carbon-eco-knowledge cities; making sense of a multitude of concepts promoting sustainable urbanization. J. Clean. Prod. 2015, 16, 25-38. [CrossRef]

9. Lenat, D.R.; Crawford, J.K. Effects of land use on water quality and aquatic biota of three North Carolina Piedmont streams. Hydrobiologia 1994, 294, 185-199. [CrossRef]

10. May, R. "Connectivity" in urban rivers: Conflict and convergence between ecology and design. Technol. Soc. 2006, 28, 477-488. [CrossRef]

11. Stovin, V.; Ashley, R. SuDS/BMPs/WSUD/SCMs: Convergence to a blue-green infrastructure. Urban Water 2019, 16, 403. [CrossRef] 
12. Aighewi, I.T.; Nosakhare, O.K.; Ishaque, A.B. Land Use-Land Cover Changes and Sewage Loading in the Lower Eastern Shore Watersheds and Coastal Bays of Maryland: Implications for Surface Water Quality. J. Coast. Res. 2013, 29, 10. [CrossRef]

13. Mirzaei, M.; Jafari, A.; Gholamalifard, M.; Azadi, H.; Shooshtari, S.J.; Moghaddam, S.M.; Gebrehiwot, K.; Witlox, F. Mitigating environmental risks: Modeling the interaction of water quality parameters and land use cover. Land Use Policy 2019, 14, 103766. [CrossRef]

14. McCarthy, M.J.; Muller-Karger, F.E.; Otis, D.B.; Méndez-Lázaro, P. Impacts of 40 years of land cover change on water quality in Tampa Bay, Florida. Cogent Geosci. 2018, 4, 1422956. [CrossRef]

15. Valentukeviciene, M.; Bagdziūnaite-Litvinaitiene, L.; Chadysas, V.; Litvinaitis, A. Evaluating the Impacts of Integrated Pollution on Water Quality of the Trans-Boundary Neris (Viliya) River. Sustainability 2018, 10, 4239. [CrossRef]

16. Shi, B.; Bach, P.M.; Lintern, A.; Zhang, K.; Coleman, R.A.; Metzeling, L.; McCarthy, D.T.; Deletic, A. Understanding spatiotemporal variability of in-stream water quality in urbanenvironments-A case study of Melbourne, Australia. Environ. Manag. 2019, 246, 203-213.

17. Fletcher, T.D.; Andrieu, H.; Hamel, P. Understanding, management and modelling of urban hydrology and its consequences for receiving waters: A state of the art. Adv. Water Resour. 2013, 51, 261-279. [CrossRef]

18. Storey, M.V.; Van der Gaag, B.; Burns, B.P. Advances in on-line drinking water quality monitoring and early warning systems. Water Res. 2011, 45, 741-747. [CrossRef]

19. Westland, J.C. Lower bounds on sample size in structural equation modeling. Electron. Commer. Res. Appl. 2010, 9, 476-487. [CrossRef]

20. Boker, S.; Neale, M.; Maes, H.; Wilde, M.; Spiegel, M.; Brick, T.; Spies, J.; Estabrook, R.; Kenny, S.; Bates, T.; et al. OpenMx: An Open Source Extended Structural Equation Modeling Framework. Psychometrika 2011, 76, 306-317. [CrossRef]

21. Lawrence, D.M.; Oleson, K.W.; Flanner, M.G.; Thornton, P.E.; Swenson, S.C.; Lawrence, P.J.; Zeng, X.; Yang, Z.L.; Levis, S. Parameterization Improvements and Functional and Structural Advances in Version 4 of the Community Land Model. J. Adv. Model. Earth Syst. 2011, 3, 45-56.

22. Seneviratne, S.I.; Corti, T.; Davin, E.L.; Hirschi, M.; Jaeger, E.B.; Lehner, I.; Orlowsky, B.; Teuling, A.J. Investigating soil moisture-climate interactions in a changing climate: A review. Earth Sci. Rev. 2010, 99, 125-161. [CrossRef]

23. Miserendino, M.L.; Casaux, R.; Archangelsky, M.; Di Prinzio, C.Y.; Brand, C.; Kutschker, A.M. Assessing land-use effects on water quality, in-stream habitat, riparian ecosystems and biodiversity in Patagonian northwest streams. Sci. Total Environ. 2011, 3, 612-624. [CrossRef] [PubMed]

24. Islam, M.S.; Ahmed, M.K.; Raknuzzaman, M.; Habibullah-Al-Mamun, M.; Islam, M.K. Heavy metal pollution in surface water and sediment: A preliminary assessment of an urban river in a developing country. Ecol. Indic. 2014, 48, 282-291. [CrossRef]

25. van Vliet, M.T.; Franssen, W.H.; Yearsley, J.R.; Ludwig, F.; Haddeland, I.; Lettenmaier, D.P.; Kabat, P. Global river discharge and water temperature under climate change. Glob. Environ. Chang. Hum. Policy Dimens. 2013, 23, 450-466. [CrossRef]

26. Camporeale, C.; Ridolfi, L. Interplay among river meandering, discharge stochasticity and riparian vegetation. Hydrology 2010, 382, 138-144. [CrossRef]

(C) 2020 by the authors. Licensee MDPI, Basel, Switzerland. This article is an open access article distributed under the terms and conditions of the Creative Commons Attribution (CC BY) license (http://creativecommons.org/licenses/by/4.0/). 